Est Doctor Vindobonensis

Norbertus Höslingerius

Laudamus eius opera

Quae in re fecit biblica

Deus sit ei praemium".

A o regionalnym spotkaniu sekcji środkowoeuropejskiej (AMB) Katolickiej Federacji Biblijnej w dniach od 5 do 8 września 1999 r. w opactwie Neustift (Abbatia Novacella) w następnych numerach RBL.

Kraków

KS. JERZY CHMIEL

\title{
TEMATY ROZPRAW DOKTORSKICH Z ZAKRESU BIBLISTYKI
}

\section{NA PAPIESKIM WYDZIALE TEOLOGICZNYM W KRAKOWIE}

KS. CHŁĄD STANISŁAW (diecezja częstochowska), 1980, Kościół „widowiskiem aniołów" (na podstawie pism Nowego Testamentu),

promotor: o. prof. dr hab. Augustyn Jankowski OSB 29 ,

S. EHRLICH Konstancja EMILIA OSU (urszulanka), 1974, Teologia Psalmu

promotor: ks. prof. dr hab. Stanisław Grzybek

JELONEK TOMASZ BOLESŁAW, 1974, „Kościót pierworodnych zapisanych w niebiosach" (Hbr 12, 23a). Przyczynek do eklezjologii Nowego Testamentu,

promotor: o. prof. dr hab. Augustyn Jankowski OSB

KS. ŁACH JÓZEF (diecezja tarnowska), 1977, Hesed i hasîd w świetle Psalterza, promotor: ks. prof. dr hab. Stunisław Grzybek

O. MYCIELSKI STANISLAW LUDWIK OSB (benedyktyn), 1971, Dzień paruzji Chrystusa wedlug Listu do Tesaloniczan. Obraz a treść teologiczna,

promotor: o. prof. dr hab. Augustyn Jankowski OSB 
KS. NOWAK JAN (archidiecezja krakowska), 1981, Chrystologiczna interpretacja słów ,W Duchu i w prawdzie” (J 4, 23),

promotor: ks. prof. dr hab. Władysław Smereka

KS. PREDER STANISŁAW (diecezja częstochowska), 1980, Literackoteologiczne problemy Psalmu 104,

promotor: ks. prof. dr hab. Stanisław Grzybek

KS. WOŹNIAK JERZY CM (misjonarz-lazarysta), 1981, Znaczenie starotestamentalnej formuly „, haj Jahwe”. Studium historyczno teologiczne,

promotor: ks. prof. dr hab. Stanisław Grzybek

\section{NA WYDZIALE TEOLOGICZNYM \\ PAPIESKIEJ AKADEMII TEOLOGICZNEJ W KRAKOWIE}

KS. BOGACZ ROMAN (archidiecezja krakowska), 1996, Rola hapax legomenów w przedstawieniu misji Chrystusa wedtug $\mathrm{Hbr}$ 1, 1-5, 10,

promotor: ks. prof. dr hab. Tomasz Jelonek

BRUTSCHECK JUTTA (NRD), 1986, Die Maria-Marta. Erzählung Eine redaktionskritische Untersuchung zu Lk 10, 38-42,

promotor: ks. prof. dr Heinz Schürmann

O. DĄBEK TOMASZ MARIA OSB (benedyktyn), 1982, HE AGAPE ton PNEUMATOS. Związek miłości z Duchem Świętym w Piśmie Świętym Nowego Testamentu,

promotor: o. prof. dr hab. Augustyn Jankowski OSB

KS. DYRDA JAN (diecezja gorzowska), 1986, Poczatki kapłaństwa izraelskiego w świetle kapłaństwa Kanaanitów,

promotor: ks. prof. dr hab. Stanisław Grzybek

S. GRZYMSKA URSZULA CR (zmartwychwstanka), 1996, Elementy paschalnej radości w Magnificat. Studium egzegetyczno-teologiczne,

promotor: ks. prof. dr hab. Stanisław Grzybek

KANTOR MARIA, 1997, Struktury dośrodkowe i odśrodkowe w poezji biblijnej na przykładzie psalmów pielgrzymkowych (Ps 120 - 134),

promotor: ks. doc. dr hab. Jerzy Chmiel

KS. KEMPIAK RYSZARD SDB (salezjanin), 1992, Wiara w Jezusa Chrystusa na podstawie Listu św. Pawła do Galatów. Studium egzegetyczno- teologiczne, 
promotor: ks. doc. dr hab. Jerzy Chmiel

O. KOCOŃ JACEK OC (karmelita trzewiczkowy), 1997, Czas Ducha Świętego $w$ ambiwalencji jego eschatologicznego wypetnienia wedlug Dziejów Apostolskich, promotor: ks. prof. dr hab. Tomasz Jelonek

KS. KoPEĆ STANISŁAW (diecezja tarnowska), 1990, Bóg Stwórca w Psałterzu. Studium egzegetyczno-teologiczne,

promotor: ks. prof. dr hab. Stanisław Grzybek

O. KRĄP BRONISŁAW OSPPE (paulin), 1985, Kerygmatyczne wartości ksiag Machabejskich,

promotor: ks. prof. dr hab. Stanisław Grzybek

S. KuRas GenOwefa Boguchwata OSU (urszulanka), 1984, Nadprzyrodzona motywacja cnoty czystości w listach św. Pawta,

promotor: o. prof. dr hab. Augustyn Jankowski OSB

KS. MATRAS TADEUSZ (diecezja częstochowska), 1989, Obraz Boga w księdze proroka Ezechiela. Studium egzegetyczno-teologiczne,

promotor: ks. prof. dr hab. Stanisław Grzybek

KS. OSTACH HENRYK COr (filipin), 1985, Antropologia księgi Hioba w świetle wspótczesnej teologii biblijnej,

promotor: ks. prof. dr hab. Stanisław Grzybek

KS. PINDEL ROMAN (archidiecezja krakowska), 1990, Chrystus jako arcykapłan wspótczujacy wedtug Listu do Hebrajczyków,

promotor: ks. prof. dr hab. Tomasz Jelonek

KS. PRZYBYŚ WŁADYSŁAW (diecezja tarnowska), 1984, Zagadnienie nawrócenia $w$ księdze proroka Jeremiasza. Studium egzegetyczno-teologiczne,

promotor: ks. prof. dr hab. Stanisław Grzybek

PIEKARZ DANUTA, 1997, Funkcja kosmologiczna i soteriologiczna preegzystujacego Syna Bożego w świetle Nowego Testamentu,

promotor: o. doc. dr hab. Tomasz Maria Dąbek OSB

KS. SEREMET BOGUSŁAW (diecezja tarnowska), 1997, Wpływ judaizmu na myśl eschatologiczna w Ewangelii wedlug św. Mateusza,

promotor: ks. prof. dr hab. Tomasz Jelonek

O. ŚLAZYK FRANCISZEK HERMAN OSPPE (paulin), 1986, Realizm i symbolika ważniejszych nazw miast $i$ liczb w Joz 15 i 19, 
promotor: ks. prof. dr hab. Stanisław Grzybek

KS. URBAŃSKI STANISŁAW (diecezja tarnowska), 1988, Rodzina w nauczaniu ksieggi Tobiasza i adhortacji apostolskiej „Familiaris consortio”. Studium biblijnopastoralne,

promotor: ks. prof. dr hab. Stanisław Grzybek

KS. WITCZYK STANISŁAW (diecezja kielecka), 1984, Teofania wedtug księgi Psalmów. Studium egzegetyczno-teologiczne,

promotor: ks. prof. dr hab. Stanisław Grzybek

KS. WNUK MIROSŁAW (diecezja augsburska), 1997, Melek w świetle Psatterza. Studium egzegetyczno-teologiczne,

promotor: ks. prof. dr hab. Stanisław Grzybek

O. ZDZIARSTEK ROMAN STANISŁAW OP (dominikanin), 1985, Będacy w Chrystusie. Ontyczny aspekt chrystianologii św. Pawta,

promotor: o. prof. Augustyn Jankowski OSB

$\mathbf{K}$

$\mathbf{R}$

O

$\mathbf{L}$

O

G I

\section{o. Franciszek Małaczyński OSB}

\section{O. CYPRIAN VAGAGGINI OSB I JEGO UDZIA $W$ DZIELE ODNOWY LITURGII}

Dnia 18 stycznia 1999 zmarł w Camaldoli o. Cyprian Vagaggini OSB, jeden z głównych pracowników dzieła odnowy liturgii, którego podstawy dała ogłoszona 4 grudnia 1963 Konstytucja Soboru Watykańskiego II Sacrosanctum Concilium.

Cyprian Vagaggini urodził się w Piancastagnaio w Toskanii, 3 października 1909 r. Studia licealne odbył w kolegium benedyktyńskiego opactwa św. Andrzeja w Belgii w latach 1920-1927. Dnia 5 października 1927 wstąpił do nowicjatu tego Opactwa i w następnym roku złożył pierwsze śluby. Ponieważ wykazywał wybitne zdolności, skierowano go na studia filozoficzne i teologiczne w prowadzonym przez benedyktynów Papieskim Ateneum św. Anzelma w Rzymie i na Katolickim Uniwersytecie w Lowanium. W roku 1931 obronił doktorat z filozofii, a w roku 1938 doktorat $\mathrm{z}$ teologii. 30 lipca 1934 otrzymał święcenia kapłańskie. Jeszcze 